\title{
Leadership and the fight against HIV/AIDS denialism in South Africa: A case study of the Treatment Action Campaign
}

\author{
Siphokazi Mnguni*
}

When considering how societies have faced and overcome certain challenges, the role that leadership and the leadership process play in both expected and unexpected outcomes is often overlooked. If the role of leadership is taken into account, it is often a 'top-down' approach in which the focus of the analysis is the leader and his or her traits, style and decision-making. This commentary takes a step back by presenting a situation that a society faced, namely the implementation of the South African government's HIV/AIDS policy between 1994 and 2000, and unpacking the outcomes and responses to it, in order to draw attention to the dynamism of the leadership process.

In 1990 the prevalence of HIV/AIDS in South Africa was at $0.7 \%$ but was predicted to rise even further. ${ }^{1}$ By 2002, it was considered a pandemic with $26.5 \%$ of the population infected and facing a dramatically reduced life expectancy. ${ }^{2}$ It was, however, the policy response by the Thabo Mbeki-led government (1998-2008), which led to HIV/AIDS's move from being solely a public health issue to being a contentious political one. Several factors contributed to this. First was the government's continuous denial of the causal link between HIV and AIDS. Second was the reluctance to implement antiretroviral (ARV) pilot programmes, specifically the mother-to-child transmission prevention (MTCTP) treatments and the highly active antiretroviral therapy (HAART) treatment. This reluctance was partly about economic feasibility as international pharmaceutical companies through the Pharmaceutical Manufacturers Association (PMA) took legal action against South Africa's Medicines and Related Substances Amendment Act, which allowed the country to manufacture and import cheap generic drugs produced in other developing countries such as Thailand. This lawsuit was eventually dropped in 2001 as PMA succumbed to public pressure and stood the risk of a damaged public image.

${ }^{1}$ The Presidency of South Africa (2003), Towards a Ten Year Review: Synthesis Report on Implementation of Government Programmes, October (Pretoria: The Presidency), p. 22

2 Ibid 
Beyond this were the actions of both Mbeki and the then Health Minister Mantu Tshabalala-Msimang in the public undermining of ARVs, with the latter infamously promoting the benefits of alternative remedies: beetroot, lemon and ginger. The final factor was the framing of HIV/AIDS as a tool used by the West to portray Africans as sexually promiscuous and as a strategy to undermine their economic sovereignty by encouraging reliance on international pharmaceutical companies. Even though the reality of people dying from preventable deaths was being felt on the ground, HIV/AIDS became caught in a web of political ideology.

It is within this context that civil society took it upon itself to combat HIV/AIDS by organising in pockets across the country through advocacy work, providing direct health care and providing support to those in need. The Treatment Action Campaign (TAC), founded in 1998, emerged as a leading voice. It had a multi-level approach, which pressured the government to change its policy using legal processes, social mobilisation, defiance campaigns and media campaigns. It also set up a national network which provided grassroots support through a robust HIV/AIDS literacy programme.

Traditional ideas about leadership focus on the leader, their position, their traits and the decisions they make. Leadership in reality is more nuanced and can be captured by a process-based approach, which is the main analytical lens that is used in this commentary. The chairperson and co-founder of the TAC at the time was Zackie Achmat, a radical character known to be a risk taker. Achmat is openly HIV positive and during the campaign he refused to take his ARVs until they were freely accessible to all South Africans. ${ }^{3}$ He also illegally shipped back cheap generic ARVs from Thailand to distribute to low-income HIV-positive South Africans in protest to trade barriers on cheap generic drugs. ${ }^{4}$ Achmat's traits, position and behaviour led to him being considered 'the leader' in the struggle for ARV treatment, but he was in fact a part of a larger more nuanced leadership process.

The TAC had a multi-dimensional approach, which gave it a hybrid character. Its core function was as a campaign for treatment but this soon developed into a national social movement. The TAC also operated as an organisation through which, research, teaching and advocacy work was carried out. Upon closer

\footnotetext{
${ }^{3}$ Colvin, Christopher , and Robins,Steven (2009), 'Social Movements and HIV/AIDS in South Africa',in Paul Rohleder,Leslie Swartz,Seth C. Kalichman and Leickness Chisamu Simbayi,eds.,HIV/AIDS in South Africa 25 Years On: Psychosocial

Perspectives (New York: Springer), p. 157

${ }^{4}$ Colvin, Christopher J.,and Robins,Steven (2009), p. 159
} 
scrutiny it becomes apparent that the leadership of the TAC was not solely invested in Achmat as an individual but his actions alongside those of others culminated in the overall leadership process. Individuals, who might have been considered followers of the TAC, led various programmes and processes. For instance, Vuyiseka Dubula, occupied the role of the participant or follower in TAC campaigns but was able to emerge as a leader through building TAC branches in districts in Cape Town. Dubula was then employed by the TAC where she built its Prevention and Treatment literacy programme. This was a terrain she was more familiar with being from a poor working class background herself. The TAC relied strategically on legal processes and scientific research to further its cause. A small group of legal and health experts oversaw this element of the work and in doing so wielded expert power. In fact a results-based approach to leadership would present leadership as being vested in this group. Leadership scholar Keith Grint, however, argues that such a focus on results is linear and rational and rather indicative of a management type of authority as opposed to leadership. ${ }^{5}$ This position is convincing especially considering the TAC's organisational nature. However, the emergence of a leader from this group cannot be ruled out, given the complex political nature of the overall situation.

Leadership as process stands out as the most fitting tool of analysis for this case because of its ability to capture nuance and complexity. Leadership as a process is rooted in the idea that it is 'how 'leaders' get things done that make them leaders'. ${ }^{6}$ This approach argues that situational needs require certain knowledge, skills and abilities. ${ }^{7}$ This allows for individuals who are confronted by an ambiguous situation to surrender their power to individuals that are able to define a new reality. ${ }^{8}$ Through this surrendering a leader emerges. This frames leadership as being relational and fluid in nature where 'leaders' and 'followers' can acquire either role depending on the situation. ${ }^{9}$ Even though a person is identified as a leader by consensus, leadership does not have to be vested in that one individual all the time.

\footnotetext{
${ }^{5}$ Grint, Keith (2010), Leadership: A Short Introduction (New York: Oxford University Press), p.16

${ }^{6}$ Grint, Keith (2010), p. 4

7 Pierce, Jon L. and Newstrom, John W. (2011), Leaders and the Leadership Process, $6^{\text {th }}$ edn. (New York: McGraw-Hill), p. 110

8 Pierce, Jon L. and Newstrom, John W. (2011), p.111

9 Murphy, Albert J. (1941), 'A Study of the Leadership Process', American Sociological Review,Vol.6,No.5,p. 675
} 
Achmat remained a key figure partly because of the dominant 'top-down' perception of leadership as vested in a person and position. His position as chairperson, his eccentric personality traits and his radical acts of defiance could be interpreted by followers as 'leader-like'. Achmat possessed qualities that were integral to the TAC's leadership process but these were only a part of the greater process that led to its triumph.

The TAC managed successfully to use the institutional tools of the new constitution to achieve its goals. In 2002, after a long court case that went up to the Constitutional Court, the TAC won the battle for the provision of MTCTP. ${ }^{10} \mathrm{~A}$ year later, the TAC launched its civil defiance campaign for a national rollout of HAART. ${ }^{11}$ This, alongside its MTCTP victory, started to cause internal disputes in the government. The South African cabinet voted against Mbeki and Tshabalala-Msimang, announcing that the government would nationally rollout HAART in the public sector. ${ }^{12}$

When societies face particular challenges it is useful to adopt the conceptualisation of leadership as a process to comprehensively understand its responses. This commentary shows that, at times, the understanding of leadership can be undermined because of the privileging of the person or the position. Because of the complexities of the context, particularly the multiple strategies that were deployed to achieve the set objectives, the paper shows also that leadership emergence is possible through a range of approaches. This is evidence of the fact that, in practice, the situation is more fluid than is often assumed, and this is the key influence that drives people to take up roles of the leader, manager and follower as required.

* Siphokazi Mnguni is a Fellow of the African Leadership Centre, King's College London. She has a Bachelor of Social Science degree from the University of Cape Town majoring in International Relations, Economics and Business French.

\section{BIBLIOGRAPHY}

Colvin, Christopher J.,and Robins,Steven (2009), 'Social Movements and HIV/AIDS in South Africa',in Paul Rohleder,Leslie Swartz,Seth C. Kalichman and Leickness Chisamu Simbayi,eds.,HIV/AIDS in South Africa 25 Years On: Psychosocial Perspectives (New York: Springer)

\footnotetext{
${ }^{10}$ Nattrass,Nicoli (2011), 'AIDS Policy in Post-Apartheid South Africa', in Ian Shapiro and Kahreen Tebeau, eds., After Apartheid: Re-Inventing South Africa (Charlottesville: University of Virginia Press),p.184

11 Ibid

12 Ibid
} 
Grint, Keith (2010), Leadership: A Short Introduction, (New York: Oxford University Press).

Murphy, Albert J. (1941), 'A Study of the Leadership Process', American Sociological Review,Vol.6,No.5,pp. 674-687

Nattrass,Nicoli (2011), 'AIDS Policy in Post-Apartheid South Africa', in Ian Shapiro and Kahreen Tebeau, eds., After Apartheid: Re-Inventing South Africa ( Charlottesville: University of Virginia Press),pp. 181-198

Pierce, Jon L. and Newstrom, John W. (2011), Leaders and the Leadership Process, $6^{\text {th }}$ edn. (New York: McGraw-Hill)

The Presidency of South Africa (2003), Towards a Ten Year Review: Synthesis Report on Implementation of Government Programmes, October, (Pretoria: The Presidency) 